\title{
THE HEROIC CHARACTER DECONSTRUCTION OF BHARATAYUDHA WAR IN MAHABHARATA EPIC
}

\author{
Fransiska Olivia Sipota \\ Christian Tritunggal School \\ E-mail \\ antoinettesipota@gmail.com
}

\begin{abstract}
The Mahabharata is an epic story written by Vyasa. The story tells about the heroism of Pandavas which ended in their victory at the battle of Bharatayudha against the Kauravas. People believes that the Pandavas are heroes who become the core of the epic story. The interpretation of heroism of Pandavas are believed by people because they are the children of God. In addition the Pandavas are believed as the protagonist characters who are powerful than ordinary human, they are good and honest. Through decnstructin theory the writer reveals the other side of the Pandavas that is hidden behind their heroic action. By reading and looking for the minor texts in the story, the writer finds that the Pandavas are not as heroic as people think. There are many things that make them look as ordinary human that are far from heroic attitude. Whereas Kauravas who are considered as the cowards and they have a bad character, but they have the attitudes as a hero more than Pandavas. The writer finds the binary oppositions in the text to search for the faults of Pandavas and the of goodness Kauravas that will change the view of the two main characters in the story. By using the theory of deconstruction the writer can find other truths in the story of the epic Mahabharata.
\end{abstract}

Keywords: deconstruction analysis, hero, heroism, Derrida, Mahabharata.

\section{INTRODUCTION}

Literature is a personal expression of human life. It can be the experiences, feelings, thoughts, passions, ideas and beliefs that are drawn through writings. Literary work is created to be enjoyed, understood and utilized by the people because it shows people's image. Some literature can be formed into manuscripts or canon texts that are full of values and beliefs, and those even be trusted that it really happened in the past.

Every nation has its own canon texts that create its cultures and ideal history. The text can be an ideal history 
because a canon which is read continually as a colossal story or epic tells about the glory of the heroes or gods. It makes the ideal history becomes the only true genuine history.

The people agree that the ideal history is the standard values of all human life. It is the climax of people pretention and tough accumulation to move with the values that is compromised among them. The stories inside the canon text are trusted as a life orientation that will always exist among the people.

One of the greatest canon texts that ever exist is Mahabharata epic story, a great work of Vyasa. It is a Hinduism sacred text just like Veda, Vedanta and Purana. This sacred text originally comes from India. The original work of it uses Sanskrit, the ancient language of India. Mahabharata itself is divided into 18 sacred texts or they call as Astadasaparwa (asta $=8$, dasa $=10$, parwa $=$ sacred text). Every sacred text represents one heroism story, but every story has a connection with the other stories. (Mohan Ganguli, 1896:33).

Mahabharata itself becomes Hinduism precept of four principle purposes of life. Sugandhi (2005:62) said the four principle purposes called Catur Purusartha or Catur Warga; those are Karma, Artha, Dharma, and Moksa. The central story of Mahabharata is Bharatayudha war which is just like a great civil war. In a word, Mahabharata tells about conflict between Pandavas and their cousins, Kauravas. They fought each other to seize the Hastina throne through the war. The war happened in Kurushetra field which ran for 18 days. It involved almost the entire kingdoms in India, both minor and large kingdoms.

The five Pandavas are Pandudevanata's sons from his two wives, Kunti and Madri. They are Yudhistira, Bhima, Arjuna (from Kunti), Nakula and Sadeva (from Madri). Actually, they are the avatar of gods. That is why they are very strong and kind. Yudhistira is well 
known as the kindest person in the world. People say that in his whole life he never makes a mistake or sin. Some people also say that because of his kindness, his blood is white which marks his holiness.

Bhima is known as a very strong knight among his brothers. He is different from his brothers; he has cruel face, but his heart is so kind. Arjuna is the most handsome man in the world. That is why he has so many wives in his life. He is good in archery. Nakula and Sadeva, the twin Pandavas, are the wise men. They are hard worker and like to serve their older brothers.

It is different how people usually describe about Kauravas. They represent the cowards and the wickedness. Although they are the Pandavas' cousins, Kauravas have the bad characters. All that they do are only the distractions. They are jealous with their cousins because in their view, Pandavas have everything. They have honor, the crown of the Hastina and love from people and also gods.
All the animosities are declared through their efforts to destroy the Pandavas. Everything they try to defeat Pandavas, but none of their efforts work well. The climax of their efforts to distract the Pandavas and claim the throne of Hastina is when they agreed to join the war that they call Bharatayudha. In this war, they gather the allies to win the war knightly. Thousands people die to defend their country. This is the greatest war that was ever told in the epic story. Because Bharatayudha does not only describe how to fight each other, there is a value about the art of war, an idea of respect intertwined with honor, demonstration of integrity, etc.

As it is known by public that in this epic, Pandavas always become the protagonists, but Kauravas always become the antagonists. Pandavas are considered as the knights, they are virtuous and wise. No one deny it. But everything can be seen from various points of views. There is also an opinion that says it is not fair for the 
antagonists who are always bad in the public opinion. No one is perfect; everybody has the mistakes they ever made.

Pandavas is a hundred percent the ordinary human who are also full of mistakes, though they are told as the avatar of gods. Moreover, the gods in this epic also do all kind of errors. In the other side, the Kauravas also have their own virtue. But people never see it as goodness; they think nothing of the Kauravas.

Mahabharata which are believed to be a basis of life tells about the heroic of Pandavas in the whole story. There is no harm if this epic says so; it teaches people that the good always conquers the evil, but is too one-sided view if we think nothing of the antagonists' goodness and never matter of the protagonists' errors. The antagonists will always be hated by people and will never be considered as a good example to live the life.

Facts about the literature of Mahabharata epic are not only limited by an existing story line which we read. But, as a great literary work that has ever been made, it definitely has the great purposes or meanings behind it. Every word that is already written can keep another meaning.

\section{THEORETICAL FRAMEWORK}

The theories include the characters in the literature, post-structuralism theory, and deconstruction theory that influence the characters in the Mahabharata epic.

\section{A. Character in Literature}

When we discuss about literature, we often use literary terms like character, characteristic and characterization. Character is an imaginative person who inhabits a story. They are the life of literature; they are the objects of our curiosity and fascination, affection and dislike, admiration and condemnation. As stated by Harmsworth, "Character is a brief descriptive sketch of personage who typifies some definite quality. The person is describe not as an individualized personality but as an 
example of some vice or virtue or type"

(1972: 21). But the usage of character term itself in English literature has two different meanings. First is character as an individual figure of the story. Second is translated as attitude, anxiety, emotion, desire and moral value of the individual figures themselves. According to Stanton, character can be meant as disposition (1956: 17). Sayuti explained that character is fictional personage that experiences the phenomenon in the story (1996: 43).

Nurgiyanto said that character aimed at characteristic and attitude of the characters that is interpreted by the readers (2002: 165). It shows personal qualities of the character in the story.

Judging from the character ${ }^{\text {re }}$ s role or importance in a story, characters are divided into the major/main characters and the minor/peripheral characters. The major characters can be seen from their appearance function. The minor characters are the characters which are not involved with the theme and characters in the story and they can only be seen once in a while in the story

Based on the character, there are protagonist and antagonist characters. James L. Potter in the Element of Literature said that protagonist is someone or something that gets into pressure in the story. The protagonist is a main character in literary works that is able to raise sympathies of the readers. He also said that the antagonist is the main person or things that against the protagonist. The antagonist is not always a human; basically it stands directly opposed to the protagonist and gives rise to the conflict of the story (1983: 23).

We can say that antagonist does not necessarily have to be a person. It could be death, the devil, an illness, or any challenge that prevents the main character from living happily. In fact, the antagonist could be a character of virtue in a literary work where the protagonist represents evil.

The understanding about the concept of the character cannot be 
separated from the concept of the characterizations. In a literary work, the author creates the characteristics of the figures that are able to support the figure existence itself. This is very essential because the figures should have characters that seem to live in a story. According to Potter (1967: 4), the characters of a figure are reflected through the characters' name, dialogue, action, physical appearance, figure description, soliloquy, and the comments from other figures.

\section{B. Heroism Definition}

Heroism represents the ideal of citizens transforming civic virtue into the highest form of civic action, accepting either physical peril or social sacrifice. In the twentieth-century philosopher Joseph Campbell believed that all heroes take journeys, confront the unknown, endure trials, and return home transformed-as did Buddha, Muhammad, and Jesus. Christians believe that heroes are humble and turn the other cheek. Frederich Nietzche believed that heroes were proud and forceful. Talmud said that a hero is the one who conquers his evil inclinations. Russian proverb says hero is someone who hangs on for the one minute more (Gibbon, 2002:1).

A Call to Heroism noted that the word hero comes to us from the Greek, meaning demigod. Off spring of a divine parent and a mortal parent, the heroes of Greek mythology were less than gods but greater than ordinary humans. The Greek notions a hero as a superhuman and godlike who think other people first before their private life. Later in their history, the Greeks applied the word hero to human beings, for example Alexander the Great (2002:4).

According to Shakespeare in Machbeth, he described a hero as justice, verity, temperance, stableness, bounty, perseverance, mercy, lowliness, devotion, patience, courage, and fortitude (Gibbon, 2002:5). So, the writer takes an antonym for each Shakespeare's definitions and finds the good definitions of what hero is 
not: unjust, untruthful, intemperate, unstable, stingy, wavering, vengeful, arrogant, capricious, impatient, cowardly, and volatile. Deconstructionists find the word hero meaningless. In their view, no one is selfless or noble. It criticizes that heroism is always a virtuous. Oxford Advance Learner's Dictionary describes a hero is a person who is admired by many for his noble equalities or courage (Hornby, 1995:558).

Some people describe a hero is courageous and handsome and valued glory in battle than life itself, but for other people, hero also often means oppressor. Today, people describe a hero as a person who takes an unpopular position, standing up for principle, persevering, forging accomplishment out of adversity.

People mostly demand the heroes have these four values in their life. First, the hero must be good and thus manifest moral purpose in his speech. Second, the hero must have propriety, or manly valor.
Thirdly, the hero must be true to life. And finally, the hero must be consistent.

\section{Post Structuralism}

Before we discussed about post structuralism, first we should know about what structuralism is. So structuralism is a theory that has been exist before post structuralism. It sought to bring to literary studies a set of objective criteria for analysis and a new intellectual rigor. Structuralism devoted its attention to matters of literary form (i.e. structure) rather than social or historical content.

There are four main common ideas underlying Structuralism as a general movement: firstly, every system has a structure; secondly, the structure is what determines the position of each element of a whole; thirdly, "structural laws" deal with coexistence rather than changes; and fourthly, structures are the "real things" that lie beneath the surface or the appearance of meaning.

Post structuralism is the name for a movement in philosophy that began in the 
1960s. It remains an influence not only in philosophy, but also in a wider set of subjects, including literature, politics, art, cultural criticisms, history and sociology. This influence is controversial because post structuralism is often seen as a dissenting position, for example, with respect to the sciences and to established moral values. The movement is best summed up by its component thinkers.

Some scientists believe that the later developments were already inherent in the earlier phase. One might say that post structuralism is simply a fuller working-out of the implication of structuralism. If structuralists tend to not doubt the existence of reality (that is some material, human, or social' economic substratum that lies beneath the ideas), so poststructuralists, on the other hand, do doubt the existence of reality, or at the very least they emphasize the extent to which the widely understood difference between "ideas" and "reality" is one constructed through discourse. But this formulation is not satisfactory; because it is evident that post structuralism tries to deflate the scientific pretension of structuralism (webs.wofford.edu).

According to Smith (2001), post structuralism is appropriate understood as improvements and developments of structuralism. Contemporary post structuralism ideas will never be exist without the earlier innovation of structuralism. If structuralism is heroic in its desire to master the world of artificial signs, post structuralism is comic and antiheroic in its refusal to take such claims seriously. However, the poststructuralist mockery of structuralism is almost a selfmockery; poststructuralists are structuralists who suddenly see the error of their ways.

Basically, post structuralism is a bunch of separate theories that is exist after structuralism. Young (1897: 1) said that the name of "post structuralism" is only useful as long as it has function as an "umbrella word" (kata pelingkup), that 
identify itself meaningfully in temporal and special deal with structuralism. It involves a displacement; it is an interrogation to structuralism methods and assumptions, makes a transformation of structuralism ideas by changes them to be conflicted with each other.

\section{Deconstruction Theory of Derrida}

Deconstruction is unthinkable without post structuralism. The notion of deconstruction is indissolubly linked to the name of Jacques Derrida. Derrida offers an overture towards a new complexity, to understand how our interpretations of politics, religion, or works of art are delimited by the structures allowing us to represent our ideas.

There is some notion of deconstruction according to experts as follows; lexically prefix ' de-' means a decrease, reduction, or rejection. So deconstructions can be interpreted as a reduction against the ways of the construction, in this case is an idea.
According to Derridases $\mathrm{Of}$ Gramatology, deconstruction begins with the assertion that language is inherently unstable; it utilizes Heidegger ${ }^{\text {ee }}$ s assertion that the written word can only signify meaning, and not ,mean ${ }^{\text {ee }}$ something in itself: hence, we have Derrida ${ }^{e e}$ s famous assertion that ,nothing exists outside the text"e. (Faruk. 2012:205).

We can say that deconstruction is a way to bring the contradictions that hide behind our concepts and beliefs in the text. Deconstruction suggests that language is not a stable entity, and that we can never exactly say what we mean. Therefore, literature cannot give a reader any one single meaning, because the language itself is simply too ambiguous. Deconstruction does focus on the text. It cannot be apart from the text, but its view is wider than only reading the text. The text is not limited by its meaning. Even the deconstruction refused the old structure that has been trusted. The deconstructionist rejected the notion that 
the text reflects the reality. Instead, they say that the text constructs the reality.

According to Faruk, Derrida explains that language is a temporal process. When we read a sentence, there is a meaning of the text that is always delayed. The former meaning is modified by the next meaning. In every sign there are traces of the other words that are executed by the sign so that it can be the final meaning. Furthermore, the meaning is never equal with itself because the sign that emerges in the different contexts is never completely the same (2012: 209210).

To make it easy to analyze deconstruction, the writer uses binary opposition that compares the characters of the hero in the text. To find the binary opposition of the characters, the writer uses aporia. Aporia is A Greek term denoting a logical contradiction, ,,aporia ${ }^{\text {ee }}$ is used by Derrida to refer to what he often calls the „blind spots ${ }^{e e}$ of any metaphysical argument. Hence the aporia - or the ,aporetice moment - takes the form of something that cannot be explained within standard rules of logic what distinguishes a deconstructive analysis, in other words, is that it always begins from an presence seem undeconstructible (Lucy, 2004:1-2).

There are several elements in aporia, but the writer only uses irony element. Irony is a figure of speech in which words are used in such a way that their intended meaning is different from the actual meaning of the words. It may also be a situation that may end up in quite a different way than what is generally anticipated. In simple words, it is a difference between the appearance and the reality. There are three major of irony (http://literarydevices.net/irony/):

\section{Verbal irony}

Verbal irony occurs when a speaker speaks something contradictory to what he intends to. It is an intentional product of the speaker and is contradictory to his/her emotions and actions. To define it simply, it means when a character uses 
statement with underlying meanings contrasting with its literal meanings, it shows that the writer has used verbal irony.

\section{Dramatic irony}

Storytellers use this irony as a useful plot device for creating situations where audience knows more about the situations, the causes of conflicts and their resolutions before leading characters or actors.

\section{Situational irony}

It occurs when incongruity appears between expectations of something to happen, and what actually happens instead. Thus, entirely different happens from what audience may be expecting or the final outcome is opposite to what the audience is expecting. It is also known as irony of situations that generally include sharp contrasts and contradictions.

\section{RESEARCH METHOD}

In this research, the writer uses text-oriented approach to analyze the data. According to the books of An Introduction to Literary Studies, "It is applied primordial textual science of religion, legal practice, and divination. These traditions place the main emphasize on the internal textual aspects of a literary works." (Mario Klarer, 1999: 76).

The text-oriented approach is primarily concerned with questions of the materiality of texts, including editions of manuscripts, analyses of language and style, and the formal structure of literary works. Text-oriented traditions, however, center on the text primarily investigating its formal or structural features.

Through this approach, the writer will analyze the main characters of Mahabharata that are taken part in Bharatayudha war by investigating Mahabharata epic story.

To make a simply application of deconstruction in the study of literary texts Roland Barthes does the following steps (Norris. 2002:8-9):

1. Identify the binary opposition of the text. The binary 
opposition acknowledges the human tendency to think in terms of opposition, for example, Reason/Passion, Man/Woman, Inside/Outside, Presence/Absence, Speech/Writing, etc. Derrida argued that these oppositions were arbitrary and inherently unstable. Deconstruction rejects most of the assumptions of structuralism and more vehemently "binary opposition" on the grounds that such oppositions always privilege one term over the other.

2. Oppositions are reversed by showing that there are the interdependences between the conflicting inside the text.

3. Introducing a new idea that cannot put in the old oppositional.

\section{DISCUSSION}

The first analytical step of the work of deconstruction is to find opposition pairs in the literary texts. In literature we will find the difference and contradiction which is the nature of the text. We can describe as a contradiction between the black and white which is opposite to each other, although the fact that black exists because of white and conversely. This kind of contradiction should be found in the analysis of literary works by using the theory of deconstruction.

From Mahabharata epic there are several main oppositions in the literary works, i.e.:

Pandavas - Kauravas

Bhima - Doryudhana

Arjuna - Karna

The oppositions above are the main conflict that becomes the focus of Mahabharata. The author tries to a raise the reader's sympathy for these characters.

In forming the sympathy of the readers, the author first describes the kindness of the main characters in order to create a sense of concern that leads the readers on a single interpretation, so that the readers is positioned as the supporters of the main character. Then 
the author leads the readers so that they

believe that the main characters of the story are the heroes who have all goodness to be praised. Positive imagery can make the readers believe that the protagonist as the main characters always win against the antagonists. With that structure the author hides the possibility of the presence of other meanings contained in literary texts which can be opposed meanings that are created by the author.

To find other meanings of the text, the writer will analyze one by one the oppositions above in this chapter.

\section{A. Pandavas vs Kauravas}

\section{The Heroism of Pandavas in}

\section{the Story}

The first role that can be analyzed using deconstruction theory is Pandavas and Kauravas themselves. As it is known that the Mahabharata told about these cousins that had a very contradictory character although they were born from the same ancestor called

Kuru and Bharata.

Pandavas were the sons of Pandu, King of Hastinapura. They were five brothers. In this story the five Pandavas were described as the heroes that had a very positive character because they were the descendants of the gods. They were the strong and handsome heroes. Each one of them had a privilege by grace of gods who begot them through two Pandu's wives, Kunti and Madri. Everyone knew that the Pandavas were a great warrior and had all of good things in their life.

"The celebrated Pandu, tempted by the desire of having more children wished to speak again unto his wedded wife (for invoking some other god). But Kunti addressed him, saying, 'The wise do not sanction a fourth delivery even in a season of distress. The woman having intercourse with four different men........." (Ganguli, 1896:390)

"...... this his eldest son, Yudhishthira, was born there, begotten by Dharma himself. Then that illustrious king obtained from Vayu this other son-the foremost of all mighty men-called Bhima. This other son, begotten upon Kunti by Indra, is Dhananjaya whose achievements will humble all bowmen in the world. Look here again at these tigers among men, mighty in the use of the bow, the twin children begotten upon Madri by the twin Aswins." (Ganguli, 1896:396) 
In the previous chapter, the writer

found that heroes were the offspring of god. Because all Pandavas were descendants of gods, we could say that they were heroes. They also had a superpower that was different with ordinary humans since they were sons of god. From their appearance and family background, the readers would easily describe that Pandavas were heroes.

It was different how people described the Kauravas through the story of Mahabharata. They were so evil and represent the darkness. The author described Kauravas as the negative figures even since they were born.

The story began from Gandhari, Kauravas ${ }^{\text {ee }}$ mother, conceived and bore the burden in her womb for two long years without being delivered. She was greatly afflicted at this. Then she heard that Kunti had given birth to three children and became so jealous. Impatient of the period of gestation which had prolonged so long, and deprived of reason by grief, she struck her womb with great violence without her husband"s knowing. After that a hard mass of flesh like an iron ball came out from her womb. Then by Vyasa's help, Gandhari magically had a hundred children.

Bad signs accompanied their birth. Brahmins in the palace felt that there would be a worst disaster and asked King Dhristarashtra to dispose them.

"O King, O bull among men, when these frightful omens are noticeable at the birth of thy eldest son, it is evident that he shall be the exterminator of thy race. The prosperity of all dependeth on his abandonment. Calamity there must be in keeping him." (Ganguli, 1896:369)

Their story was so contrast with the Pandavas. Although they were Pandavasee cousins, their appearance was very different with Pandavas. If the Pandavas were described as the heroes, the Kauravas were described as the villains. Pandavas were often told as a white side and Kauravas were the black side.

They were not the sons of god like Pandavas. They were only the ordinary humans who got their strength from the trainings like other people did. So we could 
not say that Kauravas were heroes, because they were ordinary people.

\section{Heroism Deconstruction of}

\section{Pandavas vs Kauravas}

People believed that Pandavas were heroes because they were sons of god, represented the goodness and the white side. They also had super power. But if we look at the text carefully, we will see that Pandavas also had a dark side that made them were unworthy to be called as heroes.

A hero is someone who cares for other people above their self-interest. He is also a humble person. We find another fact of Pandavas ${ }^{\text {ee }}$ heroism if we see it from this point of view. They were the arrogant person and they never admitted the other strength but theirs, especially Arjuna.

"Arjuna, after this, deeming himself disgraced, said unto Karna stationed amidst the brothers like unto a cliff, 'That path which the unwelcome intruder and the uninvited talker cometh to, shall be thine, O Karna, for thou shall be slain by me.' Karna replied, 'This arena is meant for all, not for thee alone, $\mathrm{O}$ Phalguna! They are kings who are superior in energy; and verily the Kshatriya regardeth might and might alone. What need of altercation which is the exercise of the weak?" (Ganguli, 1896:424).

The text above shows that Arjuna was also an ordinary person. If we compare with the explanation about the characteristic of hero, that is humble and caring for other people, in fact Arjuna had the opposite manner. He looked down to Karna just because he was a lower class person.

This happened when they were in the arena to compete who would success to lift the bow. Before Karna succeed to lift the bow, nobody complained about who he was. Arjuna himself also did not asked anything about him because he thought that he was the one who could lift the bow. When he saw Karna also did it, his pride broke. He began to complain and said that Karna was unwelcome intruder. In the previous chapter, we know that hero is someone who lives in justice and he is truthful. It means that a hero will never do something unworthy to achieve his goal. If we look at Pandavas deeds in Bharatayudha war, we will find the 
untruthful Pandavas. They won the war

with the wrong way.

“,Beholding Bhimasena of immeasurable energy filled with rage and rushing towards him, thy highsouled son, O bull of Bharata"s race, desiring to baffle his blow, set his heart on the manoeuvre called Avasthana. He, therefore, desired to jump upwards, $\mathrm{O}$ monarch, for beguiling Vrikodara. Bhimasena fully understood the intentions of his adversary. Rushing, therefore, at him, with a loud leonine roar, he fiercely hurled his mace at the thighs of the Kuru king as the latter had jumped up for baffling the first aim. That mace, endued with the force of the thunder and hurled by Bhima of terrible feats, fractured the two handsome thighs of Duryodhana. That tiger among men, thy son, after his thighs had been broken by Bhimasena, fell down, causing the earth to echo with his fall............... Beholding Duryodhana felled upon the earth like a gigantic Sala uprooted (by the tempest) the Pandavas became filled with joy. The Somakas also beheld, with hair standing on end, the Kuru king felled upon the earth like an infuriated elephant felled by a lion. Having struck Duryodhana down, the valiant Bhimasena, approaching the Kuru chief, addressed him, saying, "O wretch, formerly laughing at the disrobed Draupadi in the midst of the assembly, thou hadst, $\mathrm{O}$ fool, addressed us as "Cow, Cow! "e Bear now the fruit of that insult!" Having said these words, he touched the head of his fallen foe with his left foot. Indeed, he struck the head of that lion among kings with his foot." (Ganguli, 1896:3521-3523)

In this case, Bhima did the worst thing that made Pandavas lost their heroism aspect. He did not follow the rule of the war. The knight could not hit the foes who were dying and could not fight them when they were not holding their sword, but Bhima did it because of his grudge. From this view, the Pandavas were not the heroes as people believed. They won the victory through the untruthful way.

On the other side, Kauravas who were believed as the antagonists and had no kindness in their life, actually they were a good man. Not all Pandavas were cruel. Some of them were good friends of Pandavas.

"But Yuyutsu, moved by his friendship for the Pandavas, informed them of this. Vrikodara, however, swallowed it without any hesitation, and digested it completely." (Ganguli, 1896:403)

The text above showed us that Kauravas also had a good side. Yuyutsu was the one of a hundred Kauravas, but his appearances in the story was never be

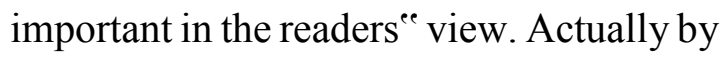
his presence, he showed the different side of Kauravas who were cruel.

If people said that Kauravas were not hero, according to the previous chapter 
about the characteristic of a hero we also could say that Kauravas were hero because they had a strength that was equal with Pandavas. The text below shows us about Kauravas Duryodhana. Krishna who was the incarnation of god Vishnu said that Bhima of the Pandavas would never win the war if he fought fairly with Durodhana.

“,Vasudeva said, “The instruction received by them hath been equal. Bhima, however, is possessed of greater might, while the son of Dhritarashtra is possessed of greater skill and hath more. If he were to fight fairly, Bhimasena will never succeed in winning the victory. If, however, he fights unfairly he will be surely able to slay Duryodhana." (Ganguli, 1896:3520)

Krishna himself admitted that Duryodhana had greater skill than Bhima so they had to fight him unfairly. The hero was someone with the great power or strength. Duryodhana had it. We could call him as a hero from that point of view.

This text also shows us the verbal irony that the great hero like Bhima should fight unfairly. Krishna said that Bhima ,is possessed of greater might ${ }^{\text {ec }}$ but in the same time he said that Bhima ,will never succeed in winning the victory" so "he fight unfairly"e so that be able to slay Duryodhana. It shows us the other the fact that Bhima was not as hero as we think.

We knew the story of burning the lac house that was planned by Kauravas. In the first time Kauravas planned it to kill Pandavas, but they did not do something that harmed Pandavas because Pandavas themselves were fulfilled that planning. A burning of lac house was done by Bhima himself. But Bhima indirectly made Duryodhana and his brothers became the suspects over burning the house of lac. All the villagers that saw the house burning began to curse Duryodhana and his minions, when Bhima himself who actually did it. This proved that Bhima was not innocent, but he was a cunning person. Because of his deeds Kauravas were hated by the people.

"Bhima then set fire to the house just where Purochana was sleeping. Then the son of Pandu set fire to the door of that house of lac. Then he set fire to the mansion in several parts all around. Then when the sons of Pandu were satisfied that the house had caught fire in several parts those chastisers of foes with their mother, entered the subterranean passage without losing any time. Then the heat and the roar 
of the fire became intense and awakened the townspeople. Beholding the house in flames, the citizens with sorrowful faces began to say, ,The wretch (Purochana) of wicked soul had under the instruction of Duryodhana built his house for the destruction of his employer"es relatives. $\mathrm{He}$ indeed hath set fire to it. $\mathrm{O}$, fie on Dhritarashtrae ${ }^{\text {ee }}$ heart which is so partial. He hath burnt to death, as if he were their foe, the sinless heirs of Pandu! O, the sinful and wicked-souled (Purochana) who hath burnt those best of men, the innocent and unsuspicious princes, hath himself been burnt to death as fate would have it.e" (Ganguli, 1896:454)

If we read carefully the text above, we would see that Kauravas were not the suspect of the lac house incident. It was true that they planned the bad for Pandavas, but the real suspect was Bhima who lit the fire. Bhima made as if it was done by Duryodhana and his brothers. As a hero, he must be true to life. Because of his deed, Kauravas should be the suspect. Bhima did not think about Kauravase ${ }^{e e}$ side. Because of the reason, we could not call him as a hero.

\section{B. Bhima vs Doryudhana \\ 1. Heroism of Bhima in Mahabharata}

Bhima and Doryudhana were cousins that had so different characters.
Bhima was a protagonist and Doryudhana was an antagonist. If Bhima was the strongest among the Pandavas, then Doryudhana was the strongest among the Kauravas.

As we knew before that all of Pandavas were the sons of god, Bhima, the second Pandava was the son of Vayu, the mighty god of wind. When his mortal father, Pandu could not have a descendant, he asked his wives to invoke the gods so that they could have one. From his first wife, he got three sons and from his second wife he got twins children.

"The god of wind thereupon begat upon her the child afterwards known as Bhima of mighty arms and fierce prowess. And upon the birth of that child endued with extraordinary strength, an incorporeal voice, O Bharata, as before, said, „This child shall be the foremost of all endued with strength. ${ }^{\text {ee" (Ganguli, 1896:388) }}$

Bhima as the son of god he was strong since he was born. He was born with the natural strength that was given by god himself. By those reasons, Bhima was born as a hero since he had all of heroism criteria. He was mighty, prowess and godlike. The author told us that Bhimaees 
skill and power were over his brothers and

his cousins, Kauravas.

"In fact, those princes were no match for Bhima in pugilistic encounters, in speed, or in skill." (Ganguli, 1896:399400)

On the other side, Doryudhana the eldest of Kauravas was decribed as a haughty person. He had the same birthday with Bhima, but the author told us that there was the bad things happened in the day when Duryodhana was born. Everyone was scare with the bad signs that accomplished Duryodhna ${ }^{e e}$ s birthday. Even the brahmans in the palace advised King Dristharatra (Kauravas ${ }^{\text {ee }}$ Father) to abandon him so that the palace would be in peace.

"As soon as Duryodhana was born, he began to cry and bray like an ass. And hearing that sound, the asses, vultures, jackals and crows uttered their respective cries responsively. Violent winds began to blow, and there were fires in various directions.................. As soon as these words were spoken, $\mathrm{O}$ Bharata, jackals and other carnivorous animals began to howl ominously and marking those frightful omens all around." (Ganguli, 1896:369)

"The assembled Brahmanas and the wise Vidura replied, 'O king, $\mathrm{O}$ bull among men, when these frightful omens are noticeable at the birth of thy eldest son, it is evident that he shall be the exterminator of thy race. The prosperity of all dependeth on his abandonment. Calamity there must be in keeping him. O king, if thou abandonest him, there remain yet thy nine and ninety sons. If thou desirest the good of thy race, abandon him, O Bharata! O king, do good to the world and thy own race by casting off this one child of thine. It hath been said that an individual should be cast off for the sake of the family; that a family should be cast off for the sake of a village; that a village may be abandoned for the sake of the whole country; and that the earth itself may be abandoned for the sake of the soul." (Ganguli, 1896:369)

From the beginning the author described that Duryodhana was the distractor that was shown implicitly in the text. It made him known as a crook in the Mahabharata.

\section{Heroism Deconstruction of Bhima vs Duryodhana}

The readers easily believe that Bhima was a great hero because the text said so. Through his self-appearance, people know that Bhima was born as a hero. If we looked at his character from another view, we would find that he was not a hero like people thought.

The other text of this story said that Bhima looked down to other people, in this case was Karna. When Arjuna complained about Karna ${ }^{e e}$ identity in the arena, 
Bhima provoked others by his words

after seeing Karna ${ }^{e e}$ s charioteer.

"Seeing the charioteer, the Pandava Bhimasena took Karna for a charioteer"s son, and said by way of ridicule, „O son of a charioteer, thou dost not deserve death in fight at the hands of Partha. As befits thy race take thou anon the whip. And, $\mathrm{O}$ worst of mortals, surely thou art not worthy to sway the kingdom of Anga, even as a dog doth not deserve the butter placed before

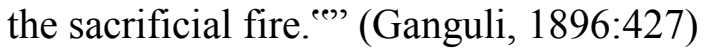

Bhima did not want his pride dropped by the lower class person like Karna who was only a son of charioteer. He used the crude words that insulted Karna. From this text, we could see that Bhima was also an ordinary person that was away from the definition of hero.

In the previous chapter, the writer found that a hero was someone who was not arrogant. A hero would never look down to other people, but he would respect people who were stronger than him. Bhima did not do it. He mocked Karna because they had different caste in society.

Another characteristic of hero according to the previous chapter, he must be good and manifest moral purpose in his speech. It was contrast with what Bhima did. After he looked down to Karna, he said the crude words to mock him. If we considered this reason to see another side of Bhima, we would find Bhima was a cruel person who could not respect other people. We could say that Bhima was also jealous with Karna because Karna had an equal power like Pandavas.

The text also said that Bhima slayed Duryodhana unfairly when they were in the war. He broke the rule of the war and he did not hear other people advice to stop the war because he just broke the law.

"Beholding Bhimasena of immeasurable energy filled with rage and rushing towards him, thy highsouled son, O bull of Bharata "e race, desiring to baffle his blow, set his heart on the manoeuvre called Avasthana. He, therefore, desired to jump upwards, $\mathrm{O}$ monarch, for beguiling Vrikodara. Bhimasena fully understood the intentions of his adversary. Rushing, therefore, at him, with a loud leonine roar, he fiercely hurled his mace at the thighs of the Kuru king as the latter had jumped up for baffling the first aim. That mace, endued with the force of the thunder and hurled by Bhima of terrible feats, fractured the two handsome thighs of Duryodhana. That tiger among men, thy son, after his thighs had been broken by Bhimasena, fell down, causing the earth to echo with his fall..................,Beholding

Duryodhana felled upon the earth like a gigantic Sala uprooted (by the tempest) the 
Pandavas became filled with joy. The Somakas also beheld, with hair standing on end, the Kuru king felled upon the earth like an infuriated elephant felled by a lion. Having struck Duryodhana down, the valiant Bhimasena, approaching the Kuru chief, addressed him, saying, "O wretch, formerly laughing at the disrobed Draupadi in the midst of the assembly, thou hadst, $\mathrm{O}$ fool, addressed us as „Cow, Cow!ee Bear now the fruit of that insult!" Having said these words, he touched the head of his fallen foe with his left foot. Indeed, he struck the head of that lion among kings with his foot

While Vrikodara, after having struck down thy son, was thus bragging and dancing madly, king Yudhishthira addressed him, saying, "Thou hast paid off thy hostility (towards Duryodhana) and accomplished thy vow by a fair or an unfair act! Cease now, O Bhima! Do not crush his head with thy foot! Do not act sinfully! Duryodhana is a king! He is, again, thy kinsman! He is fallen! This conduct of thine, $\mathrm{O}$ sinless one, is not proper. Duryodhana was the lord of eleven Akshauhinis of troops. $\mathrm{He}$ was the king of the Kurus. Do not, O Bhima, touch a king and a kinsman with thy foot. His kinsmen are slain. His friends and counsellors are gone. His troops have been exterminated. He has been struck down in battle. He is to be pitied in every respect. He deserves not to be insulted, for remember that he is a king. He is ruined. His friends and kinsmen have been slain. His brothers have been killed. His sons too have been slain. His funeral cake hath been taken away. He is our brother. This that thou doest unto him is not proper. „Bhimasena is a man of righteous behaviour ${ }^{\text {ee }}$ : people used to say this before of thee! Why then, O Bhimasena, dost thou insult the king in this way?" (Ganguli, 1896:5321-5323)

A hero would always fight fairly no matter what happened. Bhima proved himself was not a good figure of hero through his deed that slayed Duryodhana unfairly. No one was happy with his untruthful victory.

In the text above, king Yudhistira talked about his complain to Bhima with verbal irony when he said, "This conduct of thine, $\mathrm{O}$ sinless one, is not proper." $\mathrm{He}$ called Bhima as the sinless one, but in the same time he also said to Bhima that his action was not proper. It seemed that Yudhistira said it to Bhima to make Bhima remembered how people saw him as a hero or a sinless person, so he could not did the wrong way to defeat Duryodhana. It shows us that what Bhima did was not a heroic action.

The other text was said by Duryodhana who did not admit the victory of Pandavas because Bhima defeated him unfairly.

"O mighty-armed one, no one can rise superior to Time! Those of my side that have escaped with life from this battle should be informed, how I have been struck down by Bhimasena in contravention of the rules of fair fight! Many have been the very unfair and sinful acts that have been perpetrated towards 
Bhurishrava, and Bhishma, and Drona of great prosperity! This is another very infamous act that the cruel Pandavas have perpetrated, for which, I am certain, they will incur the condemnation of all righteous men! What pleasure can a righteously disposed person enjoy at having gained a victory by unfair acts? What wise man, again, is there that would accord his approbation to a person contravening the rules of fairness? What learned man is there that would rejoice after having won victory by unrighteousness as that sinful wretch, Vrikodara the son of Pandu, rejoices? What can be more amazing than this, that Bhimasena in wrath should with his foot touch the head of one like me while lying with my thighs broken? Is that person, O Sanjaya, worthy of honour who behaveth thus towards a man possessed of glory endued with prosperity, living in the midst of friends?" (Ganguli, 1896:3537)

He also noted the verbal irony to express his suffering because of Bhima. "What can be more amazing than this, that Bhimasena in wrath should with his foot touch the head of one like me while lying with my thighs broken?" He shouted a word ,amazinge to Bhima, but he added ,that Bhimasena in wrath should with his foot touch the head of one like me while lying with my thighs broken? ?e $^{\text {It was }}$ sarcasm that he used to describe what Bhima did to him. From his word we also could see what happened to Duryodhana and what Bhima did to defeat his rival. Those words gave us an image of the cruel Bhima who was actually not a hero.

Duryodhana, on the other side who considered as a coward and untruthful person, he understood that what Bhima did was wrong but he could do nothing. He respected victory that was done in a fair way.

From this side, Duryodhana seemed to be more heroic than Bhima himself. Yudhistira. In the text above, said,"He is to be pitied in every respect." He used verbal irony to describe the situation that was faced by Duryodhana. Actually Duryodhana was respected by other people since he was a king. Because his situation and condition was defeated by Bhima, he became someone that should be pitied although he was a king, someone who was a leader and should be respected by people.

Yudhistira also admitted that Duryodhana is the right person in the war. Actually he did not agree with Bhimaes 
deed because that was not a heroic way to defeat someone unfairly.

"How will Gandhari endure such poignant grief, after she hears her son, who always fought fairly, slain unfairly by us?" (Ganguli, 1896:3534)

In the text above Yudhistira showed his anxiousness how he would face Gandhari, the Kauravase mother. He himself said that Duryodhana „always fought fairlye. It meant that Yudhistira knew who the right person was during the Bharathayudha war. He did not directly say that he did not agree with

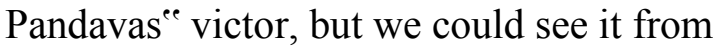
the words he said „who always fought fairly, slain unfairly by us ${ }^{\text {ee }}$. He hated what Bhima did but he could not restrain him to fight unfairly in the war.

When he died in the hands of Bhima, the heroism of Duryodhana was shown. A hero is also someone who is admired by many because of his courage. The hero also someone who stands until the last breathe of his life. Duryodhana proved it by the situation when he died.
"Upon the conclusion of these words of the intelligent king of the Kurus, a thick shower of fragrant flowers fell from the sky. The Gandharvas played upon many charming musical instruments. The Apsaras in a chorus sang the glory of king Duryodhana. The Siddhas uttered loud sound to the effect, "Praise be to king Duryodhana!" Fragrant and delicious breezes mildly blew on every side. All the quarters became clear and the firmament looked blue as the lapis lazuli. Beholding these exceedingly wonderful things and this worship offered to Duryodhana, the Pandavas headed by Vasudeva became ashamed. Hearing (invisible beings cry out) that Bhishma and Drona and Karna and Bhurishrava were slain unrighteously, they became afflicted with grief and wept in sorrow." (Ganguli, 1896:3530)

When a hero died, there would be so many people felt loss their figure. There would be tears when a good person died. When Duryodhana died, not only the earth who felt sad, but also the heaven felt the same. Maybe the text above did not mean something about how the hero should die, but from that text we would understand that Duryodhana was also a great man. For some people he was probably a hero. There was no text that noted Duryodhana was a good man, but the text itself showed that Duryodhana received a great condolence from heaven. He was greater than the 
heroes who joined the war of

Bharatayudha.

\section{Arjuna vs Karna}

\section{Heroism of Arjuna vs. Karna in}

\section{the Story}

Arjuna and Karna was the son

of Kunti from different immortal fathers.

Arjuna was descendant of god Indra and

Karna was descendant of go Surya. Both of

them were hero in tha Mahabharatha epic

story. Although they were hero and son of

god, but they had the different fate.

Karna was actually the first son of

Kunti, but he was abandoned by Kunti

since he was a baby. Because Kunti was so

young and could not receive the fact that

she was pregnant cause of her own fault.

Kunti was imparted a formula of incarnation for summoning any of the celestials she liked to give her children.

She became curious and tried to use that formula without knowing the risk of her action.

"Gratified with her respectful attentions, the sage, anticipating by his spiritual power the future (season of) distress (consequent upon the curse to be pronounced upon Pandu for his unrighteous act of slaying a deer while serving its mate) imparted to her a formula of invocation for summoning any of the celestials she liked to give her children. And the Rishi said, "Those celestials that thou shall summon by this Mantra shall certainly approach thee and give thee children.' 'Thus addressed by the Brahmana, the amiable Kunti (Pritha) became curious, and in her maidenhood summoned the god Arka (Sun). And as soon as he pronounced the Mantra, she beheld that effulgent deity--that beholder of everything in the world--approaching her. And beholding that extraordinary sight, the maiden of faultless features was overcome with surprise. But the god Vivaswat (Sun) approaching her, said, 'Here I am, O black-eyed girl! Tell me what I am to do for thee.' "Hearing this, Kunti said, 'O slayer of foes, a certain Brahamana gave me this formula of invocation as a boon, and, O lord, I have summoned thee only to test its efficacy. For this offence I bow to thee. A woman, whatever be her offence, always deserveth pardon.' Surya (Sun) replied, 'I know that Durvasa hath granted this boon. But cast off thy fears, timid maiden, and grant me thy embraces. Amiable one, my approach cannot be futile; it must bear fruit. Thou hast summoned me, and if it be for nothing, it shall certainly be regarded as thy transgression.' "Vaisampayana continued, 'Vivaswat thus spoke unto her many things with a view to allay her fears, but, $\mathrm{O}$ Bharata, the amiable maiden, from modesty and fear of her relatives, consented not to grant his request. And, $\mathrm{O}$ bull of Bharata's race, Arka addressed her again and said, 'O princess, for my sake, it shall not be sinful for thee to grant my wish.' Thus speaking unto the daughter of Kuntibhoja, the illustrious Tapana--the illuminator of the universe--gratified his wish. And of this connection there was immediately born a son known all over the world as Karna accountred with natural armour and with face brightened by ear- 
rings. And the heroic Karna was the first of all wielders of weapons, blessed with good fortune, and endued with the beauty of a celestial child. And after the birth of this child, the illustrious Tapana granted unto Pritha her maidenhood and ascended to heaven. And the princess of the Vrishni race beholding with sorrow that son born of her, reflected intently upon what was then the best for her to do. And from fear of her relatives she resolved to conceal that evidence of her folly. And she cast her offspring endued with great physical strength into the water. (Ganguli, 1896:361-362)

After Kunti abandoned him, Karna was cared by Radha, from the lowest class person. Although he was son of god, he became the lower class person because of his mother"s fault. According to the hero"s characteristics, Karna was a hero indeed. He was son of god, had a superpower because he was half god, he endured trials, and he confronted the unknown.

Arjuna, the second Pandava was also a hero just like his other brothers.

Different from Karna, Arjuna received all the happiness since he was born. He was son of god, he was born as a Prince of the court, he had all the beauty as a human, and he had superpower as a half god-human.

"The celebrated Kunti, thus addressed by her lord, invoked Sakra (the king of the gods) who thereupon came unto her and begat him that was afterwards called Arjuna. And as soon as this child was born, an incorporeal voice, loud and deep as that of the clouds and filling the whole distinctly said, addressing Kunti in the hearing of every creature dwelling in that asylum, 'This child of thine, O Kunti, will be equal unto Kartavirya in energy and Siva in prowess. Invincible like Sakra himself he will spread thy fame far and wide. As Vishnu (the youngest of Aditi's sons) had enhanced Aditi's joy, so shall this child enhance thy joy." (Ganguli, 1896:388)

“.......But Arjuna, however, outdistanced everyone in every respectin intelligence, resourcefulness, strength and perseverance. Accomplished in all weapons, Arjuna became the foremost of even the foremost of car-warriors; and his fame spread all over the earth to the verge of the sea. And although the instruction was the same, the mighty Arjuna excelled all (the princes in lightness of hand). Indeed, in weapons as in devotion to his preceptor, he became the foremost of them all. And amongst all the princes, Arjuna alone became an Atiratha (a car-warrior capable of fighting at one time with sixty thousand foes)." (Ganguli, 1896:416-417)

Both of them were known as a hero that had a different fate since they were born. They also had a different view about life, the good and the bad. The writer said it because Karna was a hero who stood in the Kauravase side. We all knew that Kauravas were the antagonist that represented the evil in the story, but Karna chose to stand before Kauravas. 


\section{Heroism Deconstruction of}

\section{Arjuna vs Karna}

They were actually the great person who only stood in different way. If Arjuna was believed as a protagonist because he was born with all of kindness, then Karna was believed as the antagonist because the position that he had as a good friend of Kauravas. The writer tried to see from the heroism aspect to know the real character of Arjuna and Karna that made them worthy to be called as a hero.

The story of Mahabharata

mostly talked about the kindness of Pandavas, but we could still find the Pandavas ${ }^{\text {ee }}$ errors. In this case was Arjuna who became the opposite of Karna in the war of Bharatayudha. We knew before that Arjuna was jealous with Karna and looked down to him because Karna had an equal power like him. He did the same to his fellow, Ekalavya who was also the pupil of their teacher, Drona. Ekalavya was a good archer who was almost as great as Arjuna. He was good because he had a ring that helped him to shoot the arrow. Arjuna was

not happy because of him.

"The Pandavas soon found out the object of their search ceaselessly discharging arrows from the bow. And beholding that man of grim visage, who was totally a stranger to them, they asked, 'Who art thou and whose son?' Thus questioned, the man replied, 'Ye heroes, I am the son of Hiranyadhanus, king of the Nishadas. Know me also for a pupil of Drona, labouring for the mastery of the art of arms.' "Vaisampayana continued, 'The Pandavas then, having made themselves acquainted with everything connected with him, returned (to the city), and going unto Drona, told him of that wonderful feat of archery which they had witnessed in the woods. Arjuna, in particular, thinking all the while, O king, Ekalavya, saw Drona in private and relying upon his preceptor's affection for him, said, 'Thou hadst lovingly told me, clasping me, to thy bosom, that no pupil of thine should be equal to me. Why then is there a pupil of thine, the mighty son of the Nishada king, superior to me?" 'On hearing these words, Drona reflected for a moment, and resolving upon the course of action he should follow, took Arjuna with him and went unto the Nishada prince. And he beheld Ekalavya with body besmeared with filth, matted locks (on head), clad in rags, bearing a bow in hand and ceaselessly shooting arrows therefrom. And when Ekalavya saw Drona approaching towards him, he went a few steps forward, and touched his feet and prostrated himself on the ground. And the son of the Nishada king worshipping Drona, duly represented himself as his pupil, and clasping his hands in reverence stood before him (awaiting his commands). Then Drona, O king, addressed Ekalavya, saying, 'If, $\mathrm{O}$ hero, thou art really my pupil, give me then my fees.' On hearing these words, Ekalavya was very much gratified, and said in reply, 'O illustrious preceptor, what shall I give? 
Command me; for there is nothing, $\mathrm{O}$ foremost of all persons conversant with the Vedas, that I may not give unto my preceptor.' Drona answered, 'O Ekalavya, if thou art really intent on making me a gift, I should like then to have the thumb of thy right hand.'Hearing these cruel words of Drona, who had asked of him his thumb as tuition-fee, Ekalavya, ever devoted to truth and desirous also of keeping his promise, with a cheerful face and an unafflicted heart cut off without ado his thumb, and gave it unto Drona. After this, when the Nishada prince began once more to shoot with the help of his remaining fingers, he found, O king, that he had lost his former lightness of hand. And at this Arjuna became happy, the fever (of jealousy) having left him." (Ganguli, 1896:416)

He was jealous when other people were more superior to him. A hero should sacrifice his happiness to help other people, but Arjuna was contradictory with that statement. He was happier if other people sacrificed their happiness for him. The last sentence of the paragraph above showed that Arjuna was not a hero as people thought. Arjuna was not as great as people believed. He was good in everything because he did not work alone by himself. Beside he was son of god; he also helped by god so that was why he won every heroic competition.
Before he met Karna, his „fathere, god

Indra had known that Karna would be the opponent of Arjuna in the Bharatayudha war. So Indra came to Karna first and asked his natural armor. Indra knew that without that natural armor, Karna would lose when he fought Arjuna.

"There was nothing on earth that the heroic and intelligent Vasusena would not give unto the Brahmanas. And Indra desirous of benefiting his own son Phalguni (Arjuna), assuming the form of a Brahmana, approached Vasusena on one occasion and begged of him his natural armour. Thus asked Karna took off his natural armour, and joining his hands in reverence gave it unto Indra in the guise of a Brahmana. And the chief of the celestials accepted the gift and was exceedingly gratified with Karna's liberality. He therefore, gave unto him a fine dart, saying, 'That one (and one only) among the celestials, the Asuras, men, the Gandharvas, the Nagas, and the Rakshasas, whom thou desirest to conquer, shall be certainly slain with this dart.' "The son of Surya was before this known by the name of Vasusena. But since he cut off his natural armour, he came to be called Karna (the cutter or peeler of his own cover).'" (Ganguli, 1896:362)

From the fact above, Arjuna was not as strong as Karna because without helping from his celestial father, he would never win against Karna. The hero was the one who used the fair way to fight his opponents. If he did not fight fairly, so he 
was not a hero. The text said that he was

superior to Karna because his father helped

him. It meant that actually Arjuna was not a hero.

The text also shows about dramatically irony," Thus asked Karna took off his natural armour, and joining his hands in reverence gave it unto Indra in the guise of a Brahmana. And the chief of the celestials accepted the gift and was exceedingly gratified with Karna's liberality. $\mathrm{He}$ therefore, gave unto him a fine dart....." Karna did not know that a person he met was a god who was actually the father of Arjuna. He gave his natural armor to someone who his child would kill him in the future. This is the bad side of Karna who always believes to someone although he would be harmed by that person.

During the Bharatayudha, Karna was in Kauravas ${ }^{e e}$ side and fought Arjuna. It was because he was loyal with his freind, Duryodhana and his brothers. He was not an evil person, but he could not choose the goodness just because of his moral duties to Duryodhana. If we saw him from this view, he was not a hero. Because he did not have courage to reject the Kauravas to not join with the war although he knew that he would fight his own brothers, Pandavas.

"Karna said, 'Without doubt, O Kesava, thou hast said these words from thy love, affection, and friendship for me, as also in consequence of thy desire of doing me good, O thou of Vrishni's race. I know all that thou hast said unto me. Morally, I am the son of Pandu, as also in consequence of the injunctions of the scriptures, as thou, $\mathrm{O}$ Krishna, thinkest. My mother, while a maiden, bore me in her womb, $\mathrm{O}$ Janardana, through her connection with Surya. And at the command of Surya himself, she abandoned me as soon as I was born. Even thus, O Krishna, I came into the world. Morally, therefore, I am the son of Pandu. Kunti, however, abandoned me without thinking of my welfare. The Suta, Adhiratha, as soon as he beheld me, took me to his home, and from her affection for me, Radha's breasts were filled with milk that very day, and she, $\mathrm{O}$ Madhava, cleansed my urine and evacuations. How can one like us, conversant with duties and ever engaged in listening to scriptures deprive her of her Pinda? So also Adhiratha of the Suta class regardeth me as a son, and I too, from affection, always regard him as (my) father....... My heart also, O Krishna, and all the bonds of affection and love, are fixed on them. From joy or fear. O Govinda. I cannot venture to destroy those bonds even for the sake of the whole earth or heaps of gold. In consequence also of my connection with Duryodhana of Dhritarashtra's race, I have, O Krishna, enjoyed sovereignty for thirteen years, 
without a thorn on my side." (Ganguli, 1896:2050)

This text shows the verbal irony of Karna when he talked about his past. "Karna said, 'Without doubt, O Kesava, thou hast said these words from thy love, affection, and friendship for me, as also in consequence of thy desire of doing me good, O thou of Vrishni's race......... . Kunti, however, abandoned me without thinking of my welfare." He said to Karna that he got the love, affection and all good things but from the beginning he was rejected or abandoned by his own Mother, Kunti. Through his word we saw the contradiction between the expectation of his life and the fact that he should endure. Through this text, we saw that Karna kept a grudge for his mother although he did not show it clearly. It made him lost the point to be a hero.

He was also innocent person who easily believed to other people who warmth his life. The text show dramatically irony when he did not know that Duryodhana only used him as a weapon to fight the
Pandavas. "My heart also, O Krishna, and all the bonds of affection and love, are fixed on them. From joy or fear. O Govinda. I cannot venture to destroy those bonds even for the sake of the whole earth or heaps of gold. In consequence also of my connection with Duryodhana of Dhritarashtra's race, I have, O Krishna, enjoyed sovereignty for thirteen years, without a thorn on my side." How pity when he could not see which one is sincere to him.

In the battlefield Kurusetra, Arjuna fought with Karna and he succeeded to kill him. And once more he did it because of the unfair way. He defeated his brother, Karna, when he was not ready to fight him because his wheel entered the ground and he did not bring any weapons. It was forbidden when someone fought his rival when he did not bring any weapons. He also rejected his mother desire to take him back to Pandavas and became her son again.

"For the sake of Dhritarashtra's son, I shall fight against thy sons to the best of my 
strength and might. I must not, however, abandon kindness and the conduct that becometh the good. Thy words, therefore, however beneficial cannot be obeyed by me now. This thy solicitation to me will not yet be fruitless. Except Arjuna, thy other sons, Yudhishthira, Bhima, and the twins, though capable of being withstood by me in tight and capable also of being slain, shall not yet be slain by me. It is with Arjuna alone, among all the combatants of Yudhishthira, that I will fight." (Ganguli, 1896:2061-2062)

He did it because the situation that forced him to do it. It was situational irony because he had to make a decision and both of those decisions were hard to do. In the end he chose to fight Pandavas because his long friendship with Kauravas.

"The earth has become impassable with heaps of slain men and steeds and elephants, and with cars broken with the shafts of Dhananjaya and Adhiratha"e son and with the numberless shafts themselves shot by them. Strewn with well-equipped cars crushed by means of mighty shafts along with the warriors and the weapons and the standards upon them, cars, that is, with their traces broken, their joints separated, their axles and yokes and Trivenus reduced to fragments, their wheels loosened, their Upaskaras destroyed, their Anukarsanas cut in pieces, the fastenings of their quivers cut off, and their niches (for the accommodation of drivers) broken, strewn with those vehicles adorned with gems and gold, the earth looks like the firmament overspread with autumnal clouds." (Ganguli. 1896:33583359)
If we compared those two
men, we saw the different of
their characters. Arjuna was more

powerful than Karna because he was

helped by god, while Karna did it by

himself. No wonder if Karna was defeated

by Arjuna. That was not because he was

weaker than Arjuna. It was just because god helped Arjuna from the beginning of the story began although he did not realize it.

The epic of Mahabharata by Vyasa told the story about Pandavas and Kauravas that represent the virtue and the evil. People believe that Pandavas as the protagonists are the heroes, while the Kauravas as the protagonists are the villain. Through deconstruction theory, the writer finds another view of the main characters.

First, the writer makes the explanation about the contradiction of Pandavas and Kauravas who became the main characters of the story. They were cousins who had very different characters. People believe 
that Pandavas were heroes because they are the offspring of gods. They are brave and they have a super power. Kauravas, on the other side they were the ordinary human that full of wickedness. But if we look at the story carefully, we will find the errors of Pandavas. They are not as heroic as people think because they did the untruthful deeds and they were not just and The Kauravas who are believed as the villain, they seem to be more heroic that Pandavas because they do the right way when they fight in the war.

Second, the writer also deconstructed about the heroism of Bhima and the cowardice of Duryodhana. As people know that Bhima the second Pandava is a hero because of his self-appearance, he is powerful; he is a son of god and so on. But actually Duryodhana is more heroic than Bhima, because he fights in the fair way.

Third, the writer makes a binary opposition between Arjuna and Karna. They were the hero who had the different fate. Karna who describes as an antagonist actually is more powerful than Arjuna. He fights by himself, but Arjuna is helped by god.

\section{References}

Carter, David. 2006. Literary Theory. Great Britain: Pocket Essentials.

Faruk. 2012. Metode Penelitian Sastra: Sebuah Penjelajahan Awal. Yogyakarta: Pustaka Pelajar.

Ganguli, Kisari Mohan. 1883-1896. The Mahabharata of Vyasa. Produced by Sacret-Texts with Distributed Proofing.

Gibbon, Petter H. and Peter J. Gomes. 2002. A Call to Heroism: Renewing America's Vision of Greatness. New York: Grove Press.

Hornby, A. S.. 1995. Oxford Advanced Learner's Dictionry. Oxford: Oxford University Press. 
Klarer, Mario. 1990. An Introduction to

Literary Studies. London: Routledge.

Royle, Nicholas. 2003. Jacques Derrida.

London: Routledge.

Lucy, Niall. 2004. A Derrida Dictionary.

UK: Blackwell Publishing Ltd.

Sayuti, A. Suminto. 2000.

Berkenalan Dengan Prosa Fiksi.

Margareth, Yuwita. 2012. Dekonstruksi

Yogyakarta: Gramedia.

Derrida Terhadap Oposisi Biner dan

Munculnya Pluralitas Makna. Skripsi.

Selden, Raman, Peter Widdowson and

Depok: Fakultas Ilmu Pengetahuan dan

Peter Brooker. 2005. A Reader's Guide to

Budaya Universitas Indonesia.

Contemporary Literary Theory. Harlow:

Pearson Education Limited.

Norris, Christopher. 2008.

Deconstruction Theory and Practice.

Semi, M. Atar. 1993. Metode Penelitian

London: Routledge.

Sastra. Bandung: PT Angkasa.

2002. Setiawan, Agung. 2012. Metafora Sebagai

Deconstruction. London: Routledge.

Pembacaan Dekonstruktif Terhadap

Nurgiyantoro, Burhan. 1995. Teori

Dekonstruksi Derrida. Skripsi. Depok:

Pengkajian Fiksi. Yogyakarta: Gadjah

Fakultas Ilmu Pengetahuan Budaya

Mada University Press

Universitas Indonesia.

Potter, James L. 1970. Element of

Surakhmad, Winarno. 1990. Pengantar

Literature. New York: The Odyssey Pres,

Penelitian Ilmiah: Dasar, Metode dan

Inc.

Teknik. Bandung: Tarsito. 
http://literarydevices.net/irony/

http://webs.wofford.edu/whisnantcj/his38

9/differences_struct_postsruct.pdf.

http://www.hindupedia.com/en/Maharshi_

Vyasa. 